\title{
Addressing Parsons in Sociological Textbooks: Past Conflicts, Contemporary Readers, and their Future Gains
}

\author{
Bettina Mahlert ${ }^{1}$ (D) \\ Accepted: 22 October 2020 / Published online: 8 December 2020 \\ (C) The Author(s) 2020
}

\begin{abstract}
The paper provides insights on the contemporary relevance of Talcott Parsons's writings by analyzing 20 textbooks from Austria, Germany, Great Britain and the United States, published in 1999-2019. Whether having knowledge of Parsons is helpful to today's students and other interested readers, and what knowledge, deserves consideration. Therefore, the paper asks: Which future gains of readers did textbook authors envision when they chose, in their own present, to discuss (or not) sociological writings from long ago? In order to understand what future opportunities authors wanted to create for readers, as well as how they chose to discuss Parsons to this end, the paper draws on Niklas Luhmann's notion of memory. The analysis reveals several key competencies that student and other interested readers might acquire through having knowledge of Parsons' writings and its critiques. These potentials would have gone unnoticed if authors had assessed Parsons's relevance only according to whether he adequately considered conflict or not, as has been done in many debates about his work until today. Moreover, through analyzing how authors remembered Parsons, I distilled two key selective criteria: First, what must be remembered in order to enable readers to acquire those competencies? Second, which memories would be impeding for readers and thus be better left out? These criteria are relevant for research, as well. Looking at the future, it would be desirable that sociologists let Parsons assist them in their research in many different ways, if possible. As a result, we might see a revival of Parsons that enables genuine advancement.
\end{abstract}

Keywords Conflict · Memory $\cdot$ Textbooks $\cdot$ Sociological theory $\cdot$ Talcott Parsons

Bettina Mahlert

Bettina.Mahlert@uibk.ac.at

1 Institute for Sociology, University of Innsbruck, 6020 Innsbruck, Austria 


\section{Introduction: Exploring How Textbooks Remember Parsons}

What is the relevance of Talcott Parsons's writings for contemporary sociology? If trying to find an answer, one might come across a puzzling disparity: While Parsons's insights and concepts are by and large absent from research, they seem to figure prominently in textbooks. But if the majority of sociologists do not use Parsons's concepts and insights today, why should students and other interested readers acquire knowledge of them? Does knowledge of Parsons enhance their learning process, independently of his relevance for professional research? Is knowledge of Parsons necessary to understand the current state of sociology? Or do textbook authors want to inspire a young generation to draw on Parsons's writings when pursuing their own research questions in the future?

Literature on textbooks suggests a different answer: Recourse to Parsons is but one manifestation of a conservatism that is widespread in textbooks across disciplines. Widely recognized contributions by Kuhn (1979) and Fleck (1979) portray the content of textbooks as a distinct form of knowledge that plays a conservative role in the reproduction of scientific ideas. According to Kuhn (1996, 1979), textbooks unavoidably "produce stabile and formulaic presentations of the main paradigm within a field" (Manza et al. 2010: 272). ${ }^{1}$ A study by Manza et al. (2010) reaffirms these observations. Reviewing the universe of sociological textbooks aimed at the US-American market between 1998 and 2004, they show that it is common practice to sort theoretical approaches into structural functionalism, conflict theory and interactionism. In this tripartite classification, Parsons figures as key representative of structural functionalism. Manza et al. note that these textbooks misguide readers about the current mainstream of the profession and present earlier theories in a distorted way, including that of Parsons. His seminal contribution The Social System (Parsons 1951) is being reduced to the endeavor to explain social systems by their underlying functions (Manza et al. 2010: 282). This, they say, ignores the role of social action in Parsons's framework, which several distinct interpreters of his work have carved out (e.g. Alexander 1984; Wenzel 1991). Manza et al. explain the distorting conservatism by supply and demand pressures on the market for textbooks, as well as by the subordinate position of most textbook authors in the university system.

In a sample of 20 textbooks from Austria, Germany, Great Britain and the United States that have been published between 1999 and 2019, I found ways of dealing with Parsons that are different from the one described by Manza and colleagues. Only four books use the tripartite classification of theoretical approaches into structural functionalism, conflict theory and interactionism. Out of these four books, three add one or two other theoretical perspectives to those three approaches, such as Rational Choice, feminism, postmodernism or post-structuralism. Only some introductions might possibly be called simplifying or distorting, and only some hold that Parsons sought to explain social systems by their underlying functions. Overall, the 20 books deal with Parsons in surprisingly diverse ways.

\footnotetext{
${ }^{1}$ Resonating with that, a key theme in the literature on sociological textbooks is their low and declining quality as well as growing homogeneity (Hobbs 1951; Wagenaar 1988; Wright 1995; cf. Manza et al. 2010: 272). However, Baker (1988) finds that textbooks of low and high quality coexist.
} 
This paper explores this variability. More specifically, I will carve out what readers learn about Parsons and how this relates to what the textbook authors want to achieve for them. The overall aim of this exploration is to get insights into the relevance of Parsons for contemporary students and other interested readers. For what is the alternative of choice to the distorting conservatism that is a key theme in the literature on textbooks? In my view, the alternative is not conservation of past works, which would mean to offer an as accurate as possible portrayal of Parsons's oeuvre, no matter what its relevance for contemporary readers. Nor is the alternative, of course, an amnesic concentration on our discipline's contemporary mainstream that ignores relevant Parsonian insights and concepts. Whether having knowledge of Parsons is helpful to today's students, and what knowledge, deserves consideration. I assume that the textbooks' authors have given thought to this question.

Therefore, the key question of this paper is: Which future gains of readers do textbook authors envision when they choose, in their own present, to discuss (or not) sociological writings from long ago? Niklas Luhmann's notion of memory offers a fruitful conceptual base for this inquiry (Luhmann 1997). Luhmann considers memory to be a continually operating infrastructure or function of social (or psychological) systems that filters all that ever happens within or to that system. ${ }^{2}$ The bulk of past events is forgotten; only very few are remembered. Therefore, Luhmann suggests, memory is not primarily about remembering but about forgetting. It is an infrastructure for inhibiting remembering, which is necessary for avoiding paralyzing complexity. Recalling in a textbook all that has ever been published in sociology is not only impossible; it would also overcharge readers, and they would rightly ask: What for? Therefore, when sociological textbooks refer to Parsons, they create a tiny isle of remembering in a huge sea of forgetting. The filtering infrastructure that produces these isles operates in the present, which means that it discriminates between forgetting and remembering depending on present relevance. At this point, the future comes in, because the "present is nothing than the distinction between past and future (...). If memory can only fulfill its function (...) in the present, this means: it has to do with the difference between past and future; it administers this difference rather than orienting one-sidedly to the past" (ibd.: 581, my translation). Through its filtering function, memory uses the past in order to establish the scope of variation of the future (ibd.: 588). Depending on what is being forgotten and what is remembered and how, different possible futures will be implicitly or explicitly projected. These futures are what is at stake in this paper: the readers' future opportunities that they might acquire through reading the different books.

Focusing on the issue of "conflict versus harmony" seems to be a fruitful guidance for these explorations. An overemphasis of "harmony" (integration, cohesion, consensus on the basis of shared values) has been a key theme in critiques of Parsons. From the late 1950 s on, critical sociological perspectives depicted his systems theory as an ideological framework that contributes to the legitimation and stabilization of existing conditions. Coser (1956) and Dahrendorf (1958) prominently charged Parsons for not recognizing the positive role of conflicts as key drivers of reform and historical change

\footnotetext{
${ }^{2}$ As Luhmann refers to communicated acts of memorizing, we might say that he deals with collective memory. However, by sharply distinguishing between social and psychological systems, he does not imply that all members of a given collective share and accept particular representations of the past that have been articulated by one or some of its members (see Beiner (2017) for criticizing memory studies in this regard).
} 
and elaborated conflict theoretical approaches that should remedy these perceived deficits. Later on, Gouldner (1970) spearheaded the opposition of Marxists, which also foregrounded conflict, change und power (see Staubmann in this issue).

These debates themselves embody a conflict, a conflict within the sociological discipline. The question of what is the role of conflict in society, which is at stake in debates about Parsons's alleged harmonism, can therefore be applied to sociology as well. When textbook authors decide whether and how to inform readers about those critiques of Parsons, they unavoidably deliver messages pertaining to the role of conflict in sociology. The question of what role conflict and harmonious collaboration actually play in sociology is important, complex and difficult to answer. Some scholars welcome conflict and competition between proponents of different theoretical paradigms, including for example Pierre Bourdieu. In his view, science is nothing but a struggle among egoists for symbolic capital - reputation -; however these struggles, and only they, effectively enable scientific progress (Bourdieu 1998). Others might suggest that scholarly dissent can be argued out in different ways, and they might consider some turf wars counterproductive, for example when cultivating a narcissism of minor differences (Law 2015). Textbook authors are faced with these questions as they have to choose how they explain to readers the multiparadigmatic state of sociology. Their choices are important because in the future, their readers will themselves choose whether to behave conflictive or cooperative towards peers, and in what way.

This seems all the more important as today, the issue of conflict vs. harmony still seems to bother sociologists. Rather than solving existing divergences, debates on how to understand Parsons's work have petered away after a period of renewed interest in his work during the 1980s-1990s. Notable in this context is Richard Münch: One of the most uncompromised and sophisticated advocates of Parsons's theory over many years, he has turned towards Bourdieu late in his academic career. When exploring ongoing processes of change in the academic world, he has recently used Bourdieu's concepts of field and struggle rather than Parsons's writings on the university, arguing that universities increasingly compete for funding and how this creates dysfunctional inequalities (Münch 2013).

Münch's turn towards Bourdieu perhaps mirrors a widely felt need to consider conflict and power when trying to unravel fundamental change and deep-seated structures of the contemporary world. Indeed, in my view, through considering conflict and power, highly valuable knowledge has been gained recently. For example, postand decolonial approaches have turned attention to the important role of colonialism in bringing about and still shaping the contemporary world. They have demonstrated that sociology has been and still is involved in producing (post-)colonial inequalities due to Western biases and ignorance of Southern colleagues, and they offer innovative proposals for remedying these shortcomings (cf. Go 2016). Another example, recent studies on internet regulation show how power structures relating to control of knowledge affect global politics, society and economics in widely unnoticed and dynamic ways (cf. Haggart et al. 2019).

This said, I fear that the issue of harmony vs. conflict might get primary attention when considering Parsons's contemporary relevance. Just because exploring conflict, power and inequality is so popular today, it might be used as an a-priori lens when evaluating theoretical approaches. In this view, if Parsons can adequately address conflict, he might be helpful; if not, he is filtered out. As a consequence, insights of Parsons that might be groundbreaking even today will go unnoticed. I do not suggest that the ability of a theory to address conflict 
cannot be a fruitful criterion when assessing its relevance; it just should not be the only one. In the 20 textbooks I analyzed, some authors offered reasons for orienting towards conflict vs. harmony when remembering Parsons for their readers, while others for equally comprehensible reasons filtered this aspect out. The same might be true in the field of research. Therefore, the key argument that I draw from my analysis is that it is better not to focus on a dichotomy of conflict vs. harmony when asking what Parsons has to offer today. This will better enable us to make the choices we consider best.

In order to let readers of this paper make up their own mind, I refrain from evaluating the textbooks. This will best enable me to expose the textbook authors' diverse reasonings. In order to foreground the future gains of the textbooks' readers, I take their perspective, exploring in an as neutral as possible way what they learn about Parsons. This approach also guided the selection of textbooks. My own assessment of the textbooks' quality was not a relevant criterion. Rather, in order to grasp as much diversity as possible in terms of authors' choices and readers' gains, the books should be heterogenous with regard to goals, audience, complexity and structure. The sample should include thematic textbooks, volumes focusing on theories, as well as books that introduce key sociological concepts. Having these criteria in mind, I went into the library of my home institution and selected an as heterogenous as possible sample from what I found there. This is of course not representative in any way. But together, the books offer insights on what students at this particular place might learn from textbooks. The institution is located in Austria, and it offers a bachelor's program in sociology as well as a master's program in social and political theory. As the sample includes books from Austria, Germany, Great Britain and the United States, it would be interesting to compare them by nation. What I can say, I did not find any striking differences except that the German books were in average more demanding and had a stronger focus on theory than the books from the other nations. My discussion focuses on a sub-set of books that together best substantiate my argument, namely, that we should assess the relevance of Parsons according to multiple criteria rather than only according to whether his framework is sensitive to conflict or not. ${ }^{3}$ Key insights are summarized in Table 1.

The following section sketches how the authors filter the past. Do they remember Parsons, and if yes, (how) do they address the role of conflict? Next, linkages to the future are explored. What is the scope of variation of the future that the memories generate? How do the memories relate to the goals that the authors communicate in their forewords and introductions? In a third step, the findings will be summarized with a focus on how authors appraise the role of conflict and harmony in sociology and in Parsons's work, and key insights will be derived.

\section{Conflict, Harmony, or Neither? Ways of Remembering Parsons}

In the following, I will first outline those memories that either depict Parsons's approach as overly harmonistic or that contradict this interpretation. Afterwards, memories that pay less or no attention to this much-discussed theme will be addressed.

\footnotetext{
${ }^{3}$ Not included in this set are the following books: Albrow (1999), Alexander (1984), Alexander and Thompson (2012), Bauman (2019), Dimbath (2016), Fulcher (2011), Harrington (2005), Joas (2007), Kröll and Stögner (2016), Law (2015), Pries (2019).
} 
Readers of Giddens's and Sutton's (2013) famous textbook Sociology learn that an overemphasis of harmony is an important feature of Parsons's theoretical framework. Parsons's approach is part of a wider framework called structural functionalism, whose key idea is that the different parts of society work together so as to produce stability and solidarity, like the organs of an organism. In addition to incorporating this idea of harmonious interaction or collaboration, structural functionalism emphasizes moral consensus: Commitment to shared values among the members of a society is supposed to produce order and balance, which is considered the normal state of society (ibd.: 23, 90 f.). Readers learn that the popularity of structural functionalism has waned because its limitations became visible. They further come to know that these limitations are not inherent in the approach of Merton, another structural functionalist, but in that of Parsons, and they consist in unduly stressing ,factors leading to social cohesion at the expense of those producing division and conflict "(ibd.: 24). As a consequence, Parsons underrated the role of divisions and inequalities such as those based on class, race and gender. However, readers also learn that the conflict-consensus polarity is one of sociology's key theoretical dilemmas. These dilemmas give rise to ongoing controversies and are not easy to solve, if at all.

Readers of Perspectives in Sociology by Cuff, Sharrock and Francis are endowed with the opposite view on Parsons's harmonism (Cuff et al. 2006: 83ff.). As in Giddens's and Sutton's book, readers are informed that Parsons's framework has been criticized for an overemphasis of harmony. However, they learn that these charges were misled. What was actually upsetting many critiques was that Parsons did not deliver a Marxist perspective that sees class conflict as key driver of societal change. Further, readers come to know that in fact, Parsons was able to describe polarized societies. He just did not consider contemporary US-American society to be polarized. Class conflicts were superficial and marginal in his view. Readers learn that this view has indirectly been confirmed by Marxists themselves, as they stepwise distanced themselves from assigning transformative power to class struggle in contemporary societies.

Like readers of Giddens and Sutton, those of Ballantine and Roberts (2015: 47ff.) learn that the issue of harmony vs. conflict is a key theme in sociology: Theories can be sorted into those who view humans as cooperative and those who view them as competitive (ibd.: 52). Belonging to the former category, structural-functionalist theories assume that "all parts of the social structure ... work together to make the whole society run smoothly and harmoniously" (ibd.: 47; emphasis added). However, while readers of Giddens and Sutton learn that structural functionalism is outdated, those of Ballantine and Roberts hear that this perspective can be applied as a tool for understanding contemporary social phenomena. Like other approaches, it has specific strengths and weaknesses. Researchers' success when trying to illuminate social phenomena depends on their ability to assess which approach is best suited for their specific research question. Applying a structural-functionalist perspective means to "look at how the parts of society ... fit together and how each part contributes to the maintenance of society" (ibd.). This also includes exploring dysfunctional activities that undermine harmony and/or maintenance of society as a whole. As concerns past debates around Parsons's work, readers are briefly informed that according to the rival conflict theory, structural functionalism in the twenty-first century fails to address key contemporary phenomena such as wars, overthrow of dictators or racial conflicts.

Readers of Chambliss and Eglitis (2019/2014) are presented a similar picture of the socalled functionalist paradigm, namely, to conceive of society as consisting of interdependent 
parts that work together in order to produce smooth functioning. Moreover, they learn that there is an underlying assumption in functionalism, according to which any existing institution or phenomenon serves a function; otherwise it would "evolve out of existence" (ibd.: 17). Correspondingly, when seeking to understand a social phenomenon, functionalists explore its contribution to the maintenance of order. More generally, readers get to know that functionalist premises induce researchers to ask specific and contingent questions when analyzing an empirical phenomenon. This is illustrated by recalling Parsons's analysis of "traditional" sex roles (instrumental - male; expressive - female): According to Parsons, the complementarity of these roles allows for mutual solidarity of the spouses through reducing competition. Readers' attention is drawn to the fact that Parsons, being led by functionalist premises, did not explore what (dis)advantages these roles transfer to men and women, respectively. Therefore, critical scholars have rejected his idea as a justification of inequality. Readers learn that a longstanding weakness of functionalism consists in "a failure to recognize inequalities in the distribution of power and resources and how those affect social relationships" (ibd: 17). ${ }^{4}$ But they also get to know a corresponding weakness of the socialconflict paradigm, namely, to overlook "forces of stability, equilibrium and consensus in society. (...) The assumption that groups have conflicting, even irreconcilable interests, and that those interests are realized by those with power at the expense of those with less power, fails to account for forces of cohesion and stability" (ibd.: 20).

Other authors, as well, recall critiques of Parsons's work but do not put an emphasis on his sensitivity to conflict. Readers of Joas and Knöbl (2004) are provided a comprehensive appraisal of Parsons's empirical and theoretical work including a discussion of its main critiques. Rather than reading that Parsons overemphasized harmonious functioning of society, they come to know him as a powerful and farsighted analyst. Through drawing on his theoretical framework, he anticipated several global developments, such as the fall of socialism and the continued or even rising relevance of religion. Readers learn that there is a "grain of truth" (ibd.: 140) in earlier critiques of Parsons, for example when refuting his depiction of modernization as a frictionless process. Because Parsons considered Western societies to be most progressive, it was understandable that the leftist student movements attacked him as a representative of the dominant societal and political system. In hindsight, however, Parsons's position might be judged more benevolently: After the fall of socialism, the rule of law, rational bureaucracy, democracy and market economy might indeed appear superior to many other types of societal order, as already claimed by Parsons. Parsons's diagnoses thus prove to be farsighted and reliable until today (ibd.).

On 95 densely lettered pages, Schneider (2008) describes in detail how Parsons developed his theory from the 1930s until his death. Only in the short summary of this recollection do readers learn that Parsons's oeuvre has been criticized and how. A first critique, Parsons only offered a descriptive analysis of functional relations but did not explain real-world processes and actions. While this is true, Schneider says, whether it is possible at all to establish causal explanations for large-scale macrosocial processes, as addressed by Parsons, is controversial among sociologists. In place of causal

\footnotetext{
${ }^{4}$ Similarly, readers of Kröll and Stögner (2016: 35) learn that there is an inherent tendency in structuralfunctionalist thinking to (over)emphasize the aspects of systems maintenance and thus to neglect the aspects of conflict and change. The tendency towards conformism, they say, corresponds to the practice of devaluing promotion of change as deviance.
} 
explanation, readers learn, Parsons offered a theory of evolution. "The analysis of cultural and institutional variants as well as their selection describes social structures as evolutionarily successful problem solutions. In doing so, the focus is on explicating the specific social functions that the newly emergent structures fulfill, and on exploring the follow-up developments that they make possible" (Schneider 2008: 178, my translation).

According to a second critique, Parsons continually relied on his AGIL-scheme. This analytical scheme, Schneider says, has produced interesting results and renders Parsons's theory highly consistent. At the same time, it is a like a straitjacket that restrains further theory building and prevents researchers from sufficiently considering the particularities of specific empirical phenomena. Still, the enormous scope and consistency of Parsons's theoretical framework has given direction to more recent engagements in theory-building (Habermas, Luhmann) (Schneider 2008: 178 f.). Readers do not get to know that Parsons was also criticized for an overemphasis of harmony. They do learn that the problem of order was a continuous reference point for Parsons when developing his theory. But they do not hear that this led him to produce a harmonistic, over-integrated picture of society.

By showing how Parsons built his theoretical framework over decades, Schneider offers a particular form of remembering: He describes a past process in concrete detail, including temporal markers that identify stages (of theoretical development) and key events (i.e. Parsons's analytical decisions). Kruse (2018) also uses temporal markers but applies a different filter: Rather than recalling how Parsons developed his theory, he remembers the historical context to which he was exposed during his academic career (Kruse 2018: 12). Kruse also recalls critiques of Parsons and mentions that they informed the creation of several new approaches later on.

In addition to the use of temporal markers, Luhmann identifies a fundamentally different form of remembering: Past events can be "condensed" into "objects" that can be used recurrently (Luhmann 1997: $580 \mathrm{f}$.). Void of temporal markers, these objects relieve memory. In our context, examples might be concepts or theoretical approaches. Thus, as described, Giddens and Sutton, Ballantine and Roberts as well as Chambliss and Eglitis all present structural functionalism as a rather compact entity that can be used in sociological analysis. They do this by filtering out information on its genesis. Nassehi (2011) even takes one step further. In his Sociology. Ten introductory lectures he does not introduce any theoretical approaches or perspectives, including that of Parsons. Rather, he exclusively picks concepts that he considers fruitful for understanding social phenomena today, such as "role", "interaction" or the notion of double contingency introduced by Parsons. Readers are not being informed about past publications that introduced, discussed and modified these concepts. Instead, they are shown how they elucidate contemporary social phenomena.

By way of concrete examples, readers come to know that some concepts - some of the many condensed pasts that today's sociologists have available - could be more effectively used than they are today. One case in point is the prevailing understanding of societies in the modern world, paradigmatically represented by Parson's concept of a national society. This notion is inadequate for two reasons (ibd.: 117ff.). First, like Albrow (1999) and Joas and Knöbl (2004), Nassehi points out to readers that it does not reflect globalization and transnationalization. As a solution, readers learn, the concept of world society could be used. Second, the 
notion of a national society embodies a politicized understanding. Society is depicted as an arena for articulating demands and counter-demands or is associated with obligations to solidarity. Readers learn that this understanding goes back to the origins of the discipline and was appropriate at that time. It addressed a key concern of sociologists at the time, namely, aligning with the endeavor to emancipate from aristocratic-authoritarian conservation of order (Nassehi 2011: 119). Nassehi explains how this politicized notion of society is a hindrance today: It makes it difficult to take seriously the multi-contextuality of modern society, the existence of different logics - what was already addressed by Durkheim under the label of social division of labor. An overemphasis of harmony in Parsons's view on modern societies is not addressed by Nassehi.

\section{Readers' gains: Filtering the Past through Envisioning the Future}

As shown, the textbooks filter the past in very different ways. Following Luhmann, this filtering is done dependent on what appears relevant in the present. For the purpose of this paper, the relevant present of textbooks authors is: Writing a book that will be of value to students and other interested readers. Which gains did the authors envision? Which "future present" of readers did they imagine that their books should make possible? When discussing these questions, the different forms of remembering that have been introduced in the last section will be taken as a guidance. I will show how each selected form of remembering fits to the specific gains that the respective author or team of authors envisioned for readers, and I will start with those books that remember the past in a concrete way, including temporal references (dates, episodes etc.).

Joas and Knöbl (2004) explicitly state that they understand their book as part of their process of working on an encompassing social theory adequate for today's world. But why do they consider their book important for readers? In the introduction, we learn that Joas and Knöbl seek to "respond to needs of students of social sciences" as well as to those of external readers who want to understand how social theory has developed since the Second World War (ibd.: 7). The authors do not indicate what exactly are those needs and why they seek to respond to them in a particular way. By scrutinizing how they remember the past, however, multiple, often specific gains can be discovered. I will only mention the one that specifically refers to critiques of harmonism in Parsons's work. As said, Joas and Knöbl suggest that when the leftist student movements attacked Parsons as a representative of the dominant societal and political system, this was understandable yet it misled. At the same time, Parsons indeed missed to point to frictions and divisions when describing processes of modernization. This was recognized by Parsons's most prominent adherents later on (Jeffrey Alexander, Richard Münch). Readers might take these memories as a promise and invitation: Even if Parsons's views might seem implausible or outdated to them (like to students in the 1960s), it could pay off to engage with his work. More generally, students learn that they, like everybody, are exposed to the overwhelming, potentially misguiding impressions of their own present conditions. Outstanding colleagues, even if long dead, can prevent them from being misguided by these forces. Engaging with Parsons in an openminded way can thus enable readers to go beyond everyday understandings of the 
contemporary world, which is a widely recognized capacity of sociologists. As an additional gain, by also critically engaging with the work of Parsons and other outstanding scholars, they might discover relevant weaknesses in their otherwise potent frameworks, thereby giving fresh impetus to the development of sociological theory.

As mentioned, Kruse (2018), as well, remembers historical context and explains its influence on sociological thinking. However, he does this with a different goal in mind. His History of Sociology aims to help students understand the texts that they will read during their studies. To this end, he filters out many more aspects of the past than Joas and Knöbl and presents these memories in a simple way. Kruse obviously imagines students struggling with difficult texts from bygone days und ultimately laying them aside in frustration. In contrast, having his paperback at hand, students can quickly and as needed inform themselves about those past days. As a result, they will have an easier time reading primary literature and draw more relevant knowledge out of it.

When Schneider (2008) remembers how Parsons developed his theoretical framework over time, he does not establish any links to historical context. His book presents a (selective) history of sociological theory framed as a sequence of consecutive transformations of analytical problems. With this, Schneider pursues a well-defined goal: make different strategies of theory-building visible to students and introduce them into procedures of theoretical thinking. He also seeks to introduce classic theoretical positions in a way that allows students to understand that these positions are not just conglomerations of definitions and claims. Thus, Schneider seems to perceive a fundamental lack of theoretical competence when remembering his past experiences with students. With his book, he wants to prevent this deplorable state from continuing, instead enabling students to understand and realize the potentials of sociological theory.

While Schneider depicts the history of sociological theory as a sequence of transformations of analytical problems, Esser (1999) evaluates the resultant multiparadigmatic state of the discipline differently. When remembering Parsons, he joins in with critiques of a lack of explanatory power, as discussed by Schneider. Accordingly, his book aims to offer an introduction to sociology by presenting its foundations from the standpoint of one integrative epistemological perspective (ibd.: IX). Esser extensively recalls details of Parsons's theoretical framework in its different phases and discusses its deficits. In spite of these deficits, readers learn, by describing the structures, processes and social entities of society in enormous richness and detail, Parsons made an indispensable and highly important contribution to the development of a more powerful explanatory sociology than structural functionalism had been (ibd.: 400).

As stated above, Cuff et al. (2006) consider Parsons's theoretical framework to be a powerful source and its Marxist critiques unjustified. In their book, they remember the history of sociology as a "story" of ultimately self-destructive scholarly conflict that obscured the potential of Parsons's analytical tools and those of other earlier sociologists. After critiques of Parsonian structural functionalism had politicized sociology in the late 1960s, the discipline shifted from the critique of economic inequality to that of cultural domination. Generalizing and radicalizing this critique, the turn towards poststructuralism ultimately repudiated any belief in knowledge, including sociology. Thus, sociologists have in a stepwise process turned their analytical resources against their own discipline. As it seems, Cuff et al. fear that students will be attracted by these perspectives without however being able to rationally weigh their value. As an 
alternative, their memories should enable students to answer themselves the basic questions that have been raised by critical theories up to post-structuralism in its present form, such as: "Must we recognize that talking about 'the social world' falsely implies a world out there and that what we are actually doing is playing a language game? What knowledge does it [i.e. sociology, BM] - can it - possibly give us? And does it matter anyway, as long as we experience some fun [i.e. enjoyment, jouissance, derived from the act of studying, as suggested by Derrida, BM]? Is this what the long march of sociological inquiry comes to?" (Cuff et al. 2006: 399).

Whether referring to the development of Parsons's oeuvre, to historical context, or past scholarly debates or, all books discussed so far incorporate temporal markers into their memories. In contrast, Ballantine and Roberts (2015) as well as Chambliss and Eglitis (2019/2014) by and large filter these out. As described above, these authors boil down the writings of Parsons and other "structural functionalists" to a set of assumptions and questions. They also add short instructions for its application. With this, they remember sociology's past in the form of what Luhmann calls objects ready for future use. What do these authors envision for their readers?

Ballantine's and Robert's overall goal is to teach students key competences for their personal development and their future jobs, including knowledge that is relevant to particular jobs. For example, "a schoolteacher trained in sociology may have a better understanding of classroom management, student motivation, causes of poor student learning that have causes outside the school" (Ballantine and Roberts 2015: 12). Resonating with that, Chambliss and Eglitis aim to stimulate curiosity in students about understanding social phenomena and to provide them with tools for answering their questions in a scientific (= disciplined) way. They want to teach students to do basic research and at the same time help them learn general skills demanded by employers outside academia. A key goal of Ballantine and Roberts as well as Chambliss and Eglitis thus is to enable non-academics to utilize sociology in their future life.

In light of the above-mentioned study by Manza et al. (2010), their depiction of structural functionalism appears like a paradigmatic example of the distorting conservatism that is typical for textbooks. Manza and colleagues explain this conservatism by pointing to market forces and structures of inequalities, i.e. the textbook authors' subordinate position in the university system. One might ironically complete their illuminating analysis in a reflexive turn, arguing that their paper manifests an instance of field-specific symbolic rule in the sense of Bourdieu. While Manza and his coauthors are successful researchers in reputed institutions, most of the textbooks' authors work as instructors at teaching colleges, where "serious research is less common than at the major research universities" (Manza et al. 2010: 287, emphasis mine), and where they have heavy teaching loads and often low salaries. In this light, Manza's and his coauthors' disgust for the distorting and obsolete image of sociology in those textbooks corresponds to the attitude of upper-class members as described by Bourdieu. These distinguished people devalue and even do not take seriously the hard and indispensable work of the lower classes (Bourdieu 1984). They do this by using specific categories like that of "serious research" used by Manza and co-authors, by which they subtly distinguish themselves from the authors of the books that they discuss. In contrast, through Luhmann's lens, the memories of Ballantine and Roberts as well as Chambliss and Eglitis appear to be a professional technique of 
complexity-reducing, relieving and a future-oriented form of coping with the past in service of their readers: condensing the past of our discipline into objects that are available for future use in jobs outside academia. ${ }^{5}$

A remarkable exception in light of Manza et al.'s study, renowned sociologist Giddens, as well, chooses this simplifying form of remembering, while at the same time criticizing Parsons's emphasis of harmony. His and his coauthor's goal is to inspire a new generation of sociologists - make them get excited about understanding past and present societal transformations. To this end, they say, they seek to avoid overburdening and frustrating readers with complex theory and sociological jargon (Giddens and Sutton 2013: xxi; 5 f.). Moreover, they chose the form of a thematic textbook. Building on cutting-edge research in their thematic chapters, they discuss past and - more extensively - present transformations in a well-comprehensible way.

As mentioned above, Nassehi (2011) does not remember Parsons's theoretical framework nor does he recall debates about his perceived neglect of conflict. This fits with his goal as well as with his specific strategy of achieving it. Nassehi wants to teach students to look at the world in a sociological way through using key concepts like action, habitus, role, or society as lenses. He imagines that reading his consciously small and easily-written book will be like a meditation, an "exercitation" (ibd.: 8) that creates self-assurance and helps to practice and observe one's own perspective. To this end, Nassehi tells a story - episodes from the life of a fictitious person, "Mister A", who later in the book comes to be known as Paul. And he demonstrates what we can "see" when looking at these episodes through the lens of a set of capable concepts. Readers cannot identify which of Parsons's insights and conceptual distinctions have become incorporated into this conceptual repertoire, as his name, like that of other theorists, is not mentioned, except in some parsimonious references at the end of the book. ${ }^{6}$ Thus, Nassehi's memories just take the form of applying well-established concepts. One could say, Nassehi did the work of intellectually pervading and sounding the sociological corpus before writing his book, while Joas and Knöbl let readers participate in their ongoing work. Nassehi's radical filter seems to be tailored to his end, which is to help readers habitualize sociological thinking.

\section{Special Insights for Readers}

In the following, I will sum up my insights regarding what readers learn about the role of conflict within Parsons's writings and in sociology, and why this might be valuable for them.

Should students read all the books discussed here, they would be confronted with widely different appraisals of Parsons's oeuvre and the arguments of his critiques. They would find polar positions, with some authors suggesting that Parsons systematically focused on society's harmonious functioning (Ballantine and Roberts, Chambliss and Eglitis, Giddens and Sutton), and other authors denying that such a focus existed at all (Schneider). Again differently, some authors suggest that Parsons might have overemphasized harmony at some points but otherwise his writings contain a wealth of valuable insights and concepts (Cuff et al., Joas and Knöbl). Even a perceived emphasis on harmony is appraised differently: To Giddens and Sutton, it renders Parsons obsolete. Ballantine and Roberts, as well as

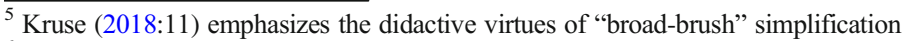

${ }^{6}$ This technique has been applied by successful earlier textbooks such as Berger and Luckman (1967).
} 


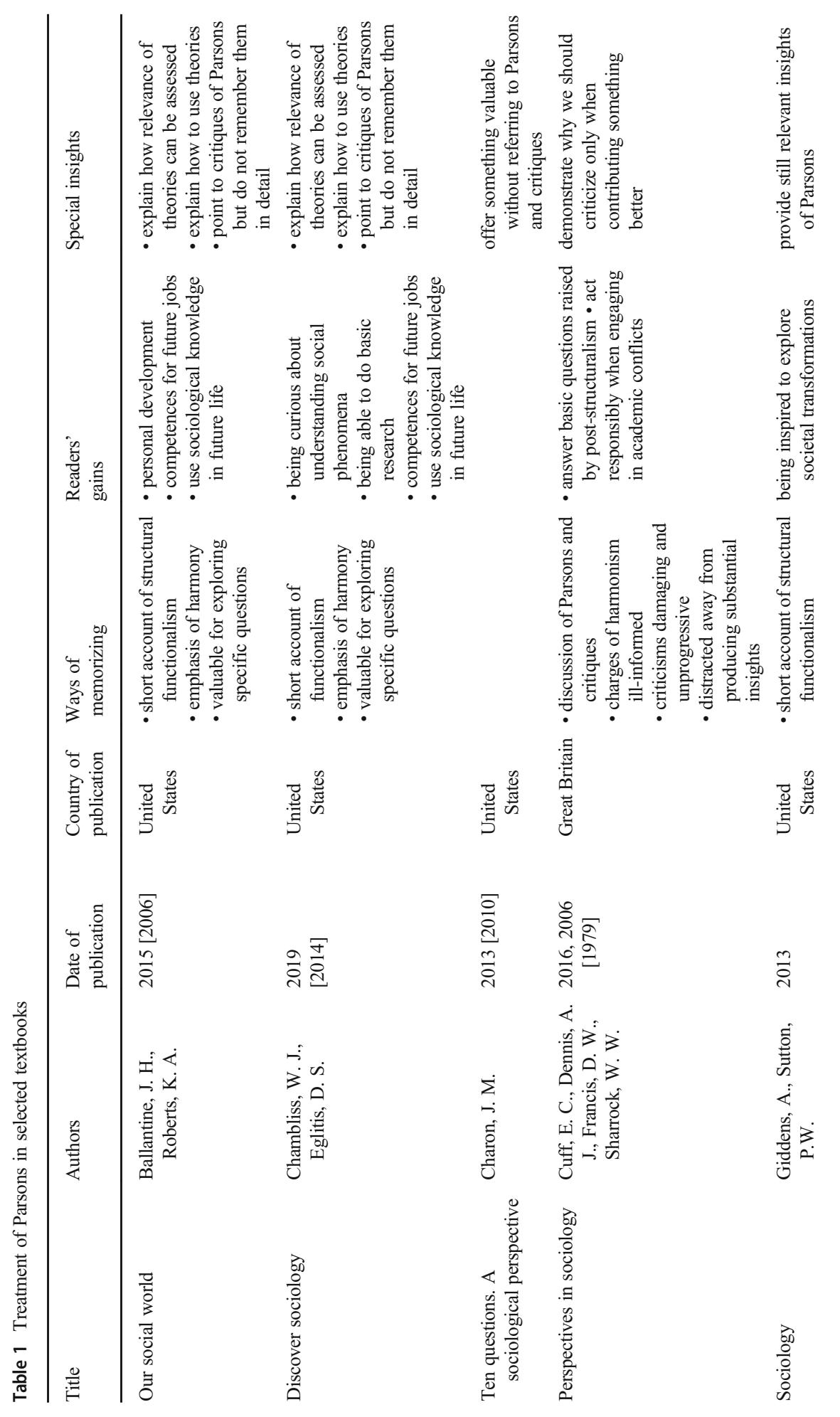




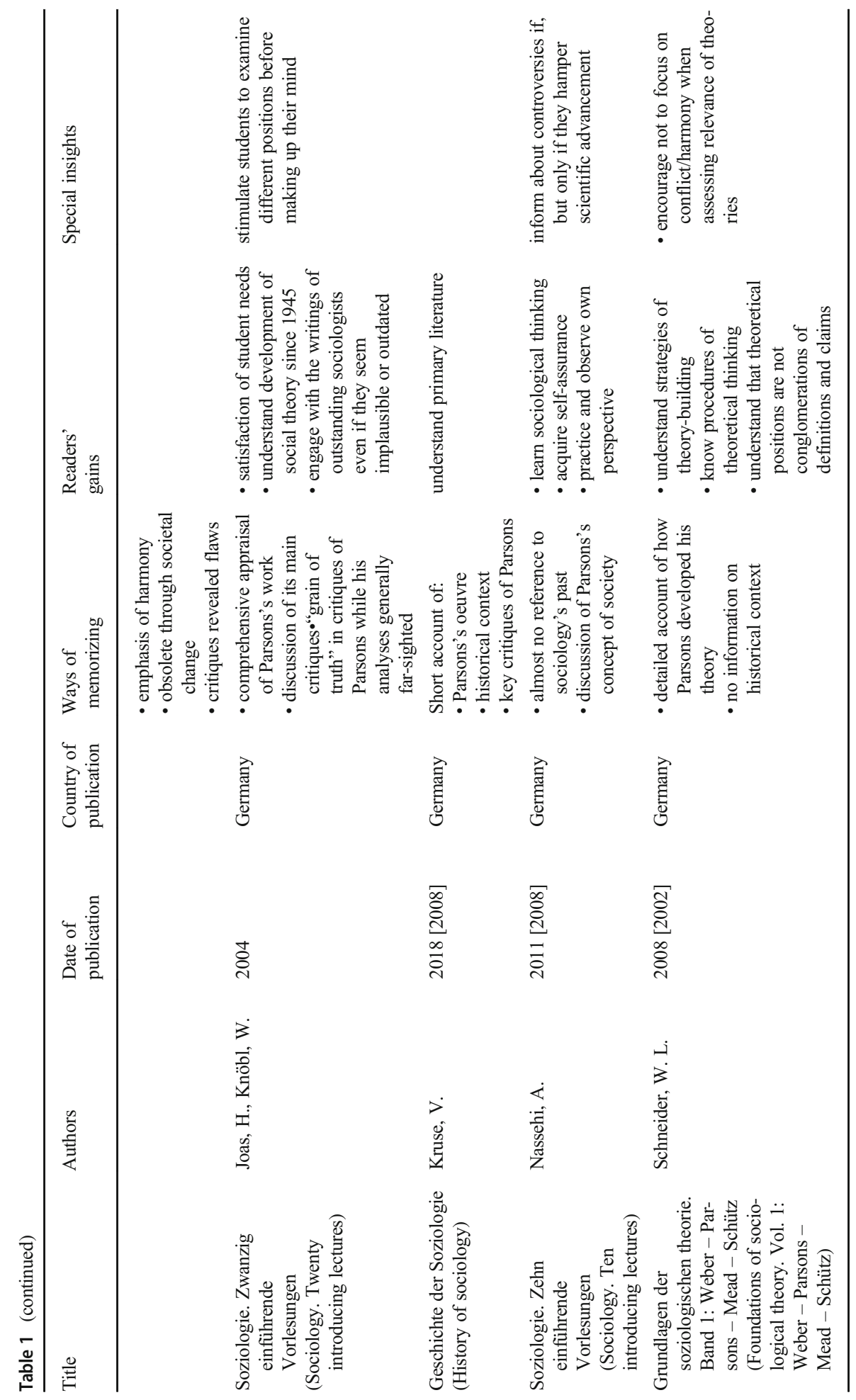


Chambliss and Wright, however, consider it a source: Like all theories, structural functionalism has blind spots, but exactly the focus on harmony that produces these blind spots allows to answer specific research questions.

What is also important, some authors claim that many of the standard critiques of Parsons's were "simply ill-informed and unjust" (Cuff et al. 2006: 103). This was also a key observation in the feedback that I got to an earlier version of this paper. When illinformed images of Parsons's work were reproduced in textbooks, reviewers said, students will "repeat the nonsense in their seminar papers". Therefore, in their own seminars they let students read the original. Whether nonsense or not - this points to a logical consequence that student readers might draw from the diversity of perspectives on Parsons work: Turn to his own writings if considering working with his theory.

How do authors deal with the existence of widely diverging views on Parsons's oeuvre and its critiques?

As a first choice, Charon (2013) decides to make a valuable contribution for his readers without explicitly remembering Parsons and debates around his work. As shown, Nassehi also makes this choice. Only at one crucial point does he make an exception, namely, when referring to Parsons's concept of society. Though Nassehi does not make his underlying reasoning explicit, we might suggest the following: By sharing a politicized notion of society, Parsons and proponents of a (more) conflictive image of society have in common a fundamental flaw that needs to be remedied. Disagreements on an overemphasis of harmony in Parsons's theory of society obviously distract researchers away from this problem, thus preventing theoretical advancement. Not recalling these disagreements in very detail in a textbook avoids bothering students with irrelevant issues. It allows to effectively make them aware of the real theoretical deficits and help them achieve genuine scientific progress.

Cuff et al. (2015: 102 f.) radicalize Nassehi's implicit observation of the potentially distracting effects of sociological controversies. In their view, conflict theory only served to position oneself against Parsons but did not add anything theoretically substantial beyond its Weberian foundations. Even more, Marxists had to go through decades of research and internal controversy in order to arrive at an insight that Parsons had offered to them long before, namely, that class conflict would not function as a transformative power in US-American society. This shows that scholarly conflict can assault and massively damage colleagues when taking a well-founded yet unpopular position. What is more, those debates have kept sociologists away from producing substantial knowledge of the social world. The lesson for readers: If criticizing others, they should themselves be able to contribute something better. If they can't, better "shut up". Otherwise, they might damage those criticized, themselves and the overall discipline.

Like Cuff et al., Joas and Knöbl also emphasize that Parsons contributed valuable insights and concepts which have been overlooked by (some of) his critiques. At the same time, in their view, some criticisms uncovered real weaknesses in Parsons's framework. This has helped theorists who seek to advance Parsons's proposals (Alexander, Münch) to consider these deficits in their own work. From this, students can learn that it will pay off to examine different theoretical positions before prematurely making up their mind. Ballantine and Roberts (2015) as well as Chambliss and Eglitis (2019/2014) offer concrete proposals for how this can be done.

Like these latter authors, Giddens and Sutton turn towards empirical topics rather than recalling in detail debates about Parsons's work. In their thematic chapters, they examine the 
relevance of Parsons's concepts for the respective issues. By asking whether and how Parsons can contribute to understanding contemporary phenomena, they filter his past writings according to their present relevance. As a result, readers learn that "it is possible to see the contemporary diversity of family forms (and marriage) as evidence of (...) adaptation of a key social institution to a rapidly changing social life" (Giddens and Sutton 2013: 370). Another relevant insight, school education instils in pupils orientation to individual achievement, which is a key value in industrialized societies (ibd.: 835). And Parsons's notion of the sick role allows to link individual illness to wider healthcare systems (ibd.: 405). All these observations are neither linked to a harmonistic picture of society nor do they eo ipso point to conflict. Thus, from Giddens and Sutton, readers can learn: Even if Parsons's theoretical framework reflects the stability and harmonious functioning of industrialized societies in the decades following the Second World War, it still pays off to scrutinize how it can help to understand contemporary societies.

Schneider adds to this when depicting the history of sociological theory as a sequence of consecutive transformations of problems. He points out to students that it is misleading to draw generalized "performance comparisons" between theoretical approaches (Schneider 2008: 17). New theoretical approaches are not useful because they disconfirm earlier theories or because they excel them through better answering the same questions. Rather, they are valuable through introducing a different set of guiding problems and then developing a theoretical perspective that offers answers to these problems. One should not play off one theory against another according to one criterion. Offering causal explanations, as demanded by Esser, would be one of these criterions, but also, of course, the issue of conflict vs. harmony. Thus, students learn that they will not be able to discover the (non)relevance of theories for their research questions if assessing them only according to whether they adequately address conflict and power or not.

\section{Conclusion}

The aim of this paper was to provide insights on the contemporary relevance of Parsons's writings by analyzing 20 textbooks from Austria, Germany, Great Britain and the United States. Which future gains of readers do textbook authors envision when they choose, in their own present, to discuss (or not) sociological writings from long ago? Following Luhmann, I conceived of memory as a continually operating infrastructure that filters the past dependent on its present relevance. Memory shelters from paralyzing complexity through forgetting the bulk of past events. Depending on what is remembered and how, different futures will be imagined. When analyzing how Parsons is remembered in the books, I focused on the issue of harmonism vs. conflict, which has been a key theme in critiques of Parsons and still is relevant. Inherent in the memories and in the forewords and introductions, I found diverse goals that the authors want to achieve - future gains of readers that the books should make possible. When exploring these gains, I focused on key competencies rather than specific concepts and insights provided by Parsons. According to the authors, knowledge of Parsons and his critiques can help readers use sociological knowledge in their future life including outside academia; act responsibly when engaging in academic conflicts; be ready to engage with the writings of outstanding sociologists even if they seem implausible or outdated; examine different positions before making up their mind; understand strategies and procedures of theory-building. We cannot see these and other 
potentials if assessing Parsons's relevance only according to whether he adequately considers conflict or not, as has been done in many debates about Parsons's work until today. Indeed, another key competency that one textbook author wants to deliver to student readers is that they must assess theories according to multiple criteria rather than only one in order to derive the best benefit from them. Moreover, through analyzing how authors filtered the past, two key criteria became visible: First, what must be remembered in order to enable them to develop these competencies? Second, which memories would be impeding for readers and thus be better left out? These seem to be important questions for sociological research as well, which have not been addressed in this paper.

When writing textbooks or doing research, we can draw on Parsons's contributions because at earlier points in time, Parsons sought to achieve goals for sociological audiences as well, and remembered the work of again earlier scholars to this end. In doing so, he was informed by his own understanding of what collaboration can accomplish for sociology, as Joas and Knöbl (2004: 43ff.) indicate in their discussion of Parsons's early work, The Structure of Social Action. When writing The Structure of Social Action, they say, Parsons had a clearly formulated goal in service of the emerging discipline in mind: To offer a firm - or firmer - basis to sociology or even to the social sciences at large by reformulating in an analytically concise way the often-diffuse thoughts of four European theorists (Alfred Marshall, Vilfredo Pareto, Max Weber and Emile Durkheim). Knöbl and Joas explicate how Parsons remembers the history of social sciences as a story of scientific progress in Structure of Social Action - a story that leads from utilitarianism to Marshall, Pareto, Durkheim and Weber directly to Talcott Parsons. One might suspect that the only aim of Parsons when telling this success story was to celebrate himself as the person who perfected the intellectual edifice of those four theorists - even if he also indicated that he expected his framework to be changed and improved in the future. Yet, Joas and Knöbl argue, Parsons could have pursued this goal in a much more comfortable and promising way. From the perspective of US-American sociologists, Europe was in a process of political decay in the late 1930s; it seemed hardly evident why one should turn - exclusively! - to European thinkers in order to establish and legitimate sociology at US-American universities. Parsons could not expect that he would get much recognition for the Structure of Social Action. At the same time, distilling a complex theoretical framework from the often-fragmentary writings of those four theorists was an extraordinarily time-consuming and arduous task - all the more as these writings were impregnated by national and personal context.

Joas and Knöbl argue that Parsons's effort and courage (which were informed by his views on collaboration among scientists) have been compensated abundantly: It was due to his creative way of dealing with the work of those classics and his specific form of theory-building that American sociology made remarkable progress and advanced to a much higher level in theory since the late 1930s. Through concentrating on a few European classics, Parsons forced sociologists all over the world to go back to the basics of their discipline. Only through his synthesis were Durkheim and Weber established as classics.

Looking at the future, I wish that readers of whichever textbooks understand they will need to "filter" what they learn from these books when formulating their own questions at a later point in time. It would be a great achievement if sociological textbooks stimulate readers to always check whether the acquired insights and tools meet the diverse requirements for achieving their particular analytical goal in a future 
present - to abandon what is not relevant anymore, preserve what is still suitable, and revise if necessary and possible. I also wish that students as well as professional researchers will stop focusing on sensitivity to conflict when assessing the relevance of Parsons's writings for their research. It would be desirable that they instead let Parsons assist them in their scholarly endeavors in many different ways, if possible. As a result, we might see a revival of Parsons that enables genuine advancement.

Authors' Contributions Not applicable.

Funding Open access funding provided by University of Innsbruck and Medical University of Innsbruck.

Data Availability Not applicable.

\section{Compliance with Ethical Standards}

Conflicts of Interest/Competing Interests The author declares that there is no conflict of interests.

Code Availability Not applicable.

Open Access This article is licensed under a Creative Commons Attribution 4.0 International License, which permits use, sharing, adaptation, distribution and reproduction in any medium or format, as long as you give appropriate credit to the original author(s) and the source, provide a link to the Creative Commons licence, and indicate if changes were made. The images or other third party material in this article are included in the article's Creative Commons licence, unless indicated otherwise in a credit line to the material. If material is not included in the article's Creative Commons licence and your intended use is not permitted by statutory regulation or exceeds the permitted use, you will need to obtain permission directly from the copyright holder. To view a copy of this licence, visit http://creativecommons.org/licenses/by/4.0/.

\section{References}

Albrow, M. (1999). Sociology: The basics. London and New York: Routledge.

Alexander, J. C. (1984). The modern reconstruction of classical thought: Talcott Parsons. Berkeley: University of California Press.

Alexander, J. C., Thompson, K. (2012) [2008]. A contemporary introduction to sociology. Culture and society in transition ( $2^{\text {nd }}$ ed.). Boulder: Paradigm Publishers.

Baker, P. (1988). Sociology textbooks: managing clones or writing works of distinction. Teaching Sociology, 16(4), 281-282.

Ballantine, J. H., Roberts, K. A. (2015) [2006]. Our social world (condensed version) (3rd ed.). Thousand Oaks: Sage.

Bauman, Z., \& May, T. (2019) [1990]. Thinking sociologically. Oxford: Blackwell.

Beiner, G. (2017). Troubles with remembering; or, the seven sins of memory studies. In: Dublin Review of Books 11(1), https://www.drb.ie/essays/troubles-with-remembering-or-the-seven-sins-of-memory-studies (last retrieved 19.08.2020).

Berger, P., \& Luckman, T. (1967). The social construction of reality. A treatise in the sociology of knowledge. New York: Anchor Books.

Bourdieu, P. (1984). Distinction. London: Routledge.

Bourdieu, P. (1998). Is a disinterested act possible? In P. Bourdieu (Ed.), Practical reason. On the theory of action. Stanford: Polity Press.

Chambliss, W. J., \& Eglitis, D. S. (2019/2014). Discover sociology (4th ed.). Thousand Oaks: California.

Charon, J. M. (2013) [2010]. Ten questions. A sociological perspective ( $8^{\text {th }}$ ed.). Belmont: Wadsworth. 
Coser, L. (1956). The functions of social conflict. Glencoe: Free Press.

Cuff, E. C., Sharrock, W. W., \& Francis, D. W. (2006) [1979]. Perspectives in sociology (5th ed.). London: Routledge.

Cuff, E. C., Sharrock, W. W., Francis, D. W. (2015) [1979]. Perspectives in sociology (6th ed.). London: Routledge.

Dahrendorf, R. (1958). Out of utopia: toward a reorientation of sociological analysis. American Journal of Sociology, 64(2), 115-127.

Dimbath, O. (2016) [2011]. Einführung in die Soziologie (Introduction to sociology) (3rd ed.). Paderborn: Fink.

Esser, H. (1999) [1993]. Soziologie. Allgemeine Grundlagen (Sociology. General foundations) (3rd ed.). Frankfurt a. M.: Campus.

Fleck, L, 1979 [1935]. Genesis and development of a scientific fact. Chicago: University of Chicago Press.

Fulcher, J., Scott, J. (2011) [1999]. Sociology (4th ed.). Oxford: Oxford University Press.

Giddens, A., \& Sutton, P.W. (2013) [1989]. Sociology (8th ed.). Cambridge: Polity Press.

Go, J. (2016). Postcolonial thought and social theory. Oxford: Oxford University Press.

Gouldner, A. (1970). The coming crises of sociology. New York: Basic Books.

Haggart, B., Henne, K., \& Tusikov, N. (Eds.). (2019). Information, technology and control in a changing world. Understanding power structures in the 21st century. London and New York: Palgrave Macmillan.

Harrington, A. (2005). Modern social theory. An introduction. Oxford: Oxford University Press.

Hobbs, A. H. (1951). The claims of sociology: A critique of textbooks. Harrisburg: Stackpole.

Joas, H. (ed.) (2007) [2001]. Lehrbuch der Soziologie (Textbook of sociology) (3rd ed.). Frankfurt and New York: Campus.

Joas, H., \& Knöbl, W. (2004). Soziologie. Zwanzig einführende Vorlesungen (Sociology. Ten introducting lectures). Frankfurt a. M.: Suhrkamp.

Kröll, F., Stögner, K. (2016) [2015]. Sozialwissenschaftliche Denkweisen. Eine Einführung (Modes of thought in the social sciences. An introduction) (2nd ed.). Wien: New Academic Press.

Kruse, V. (2018) [2008]. Geschichte der Soziologie (History of sociology) (3 ${ }^{\text {rd }}$ ed.). Konstanz: UVK.

Kuhn, T. (1979). The essential tension: Selected studies in scientific tradition and change. Chicago: University of Chicago Press.

Kuhn, T. (1996) [1962]. The structure of scientific revolutions (3rd ed.). Chicago: University of Chicago Press.

Law, A. (2015). Social theory for today. Making sense of social worlds. Los Angeles: Sage.

Luhmann, N. (1997). Gedächtnis (Memory). In: N. Luhmann, Die Gesellschaft der Gesellschaft (Theory of society) (1st vol.) (pp. 576-594). Frankfurt a. M.: Suhrkamp.

Manza, J., Sauder, M., \& Wright, N. (2010). Producing textbook sociology. European Journal of Sociology, 51(2), 271-304.

Münch, R. (2013). Academic capitalism. Universities in the global struggle for excellence. London: Routldege.

Nassehi, A. (2011) [2008]. Soziologie. Zehn einführende Vorlesungen (Sociology. Ten introductory lectures) (2nd ed.). Wiesbaden: VS.

Parsons, T. (1951). The social system. Glencoe: Free Press.

Pries, L. (2019) [2014]. Soziologie. Schlüsselbegriffe, Herangehensweisen, Perspektiven (Sociology. Key concepts, approaches, perspectives) (4th ed.). Weinheim: Beltz.

Schneider, W. L. (2008) [2002]. Grundlagen der soziologischen Theorie. Band 1: Weber-Parsons - MeadSchütz. (Foundations of sociological theory. Vol. 1: Weber-Parsons - Mead - Schütz) (3rd ed.). Opladen: Westdeutscher Verlag.

Wagenaar, T. C. (ed.) (1988). "Special issue on textbooks." Teaching Sociology 16(4).

Wenzel, H. (1991). Die Ordnung des Handelns. Talcott Parsons's allgemeines Handlungssystem (The order of action. Talcott Parsons's general action system). Frankfurt: Suhrkamp.

Wright, R. A. (1995). Was there a "golden past" for the introductory sociology textbook? A citation analysis of leading journals. The American Sociologist, 26, 41-48.

Publisher's Note Springer Nature remains neutral with regard to jurisdictional claims in published maps and institutional affiliations. 